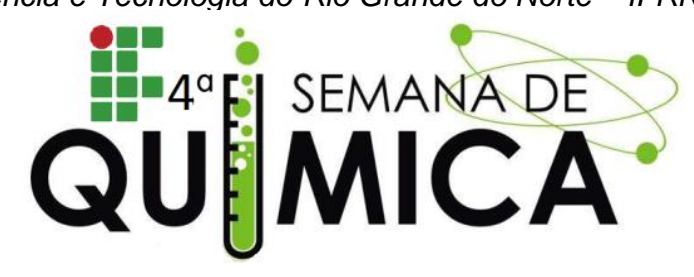

\title{
JOGO DIDÁTICO: CHEMICAL QUIZ (QUIZ QUÍMICA) DO PIBID-IFRN-CAMPUS APODI
}

*COSTA, K.C.P, (IFRN), SANTOS, H.O. (IFRN), FERNANDES, P.R.N (IFRN), BERTINI, L. M. (IFRN), ALVES, L. A. (IFRN), FILHO, A.F. (EEPMZG)

Palavras Chave: Ensino-aprendizagem, Jogo didático, PIBID.

\section{INTRODUÇÃO}

A Química atualmente tem se mostrado como uma disciplinar considerada um tanto difícil para grande parte dos estudantes das Escolas Públicas, os quais muitas vezes culpam a metodologia do docente, alegando os mesmos que ela não é eficaz (MELO, 2005). Em vista disso, é de grande importância a utilização de novas metodologias de ensino pelos docentes, elaborando novas formas de repassar o conhecimento e ao mesmo tempo deixando a aula mais dinâmica e interessante para o aluno. Nesse contexto foi desenvolvido o jogo Quiz Química, o qual tem por objetivo auxiliar o aluno no processo de ensino-aprendizagem de Tabela Periódica por meio da utilização de atividades lúdicas.

\section{METODOLOGIA}

O jogo Quiz Química foi desenvolvido em forma de um tabuleiro, contendo 28 espaços vazios (Figura 01), o mesmo foi aplicado na turma de 9o ano matutino da Escola Estadual Professora Maria Zenilda Gama. Valendo ressaltar que este jogo pode ser aplicado em outras turmas do Ensino Fundamental e Médio.

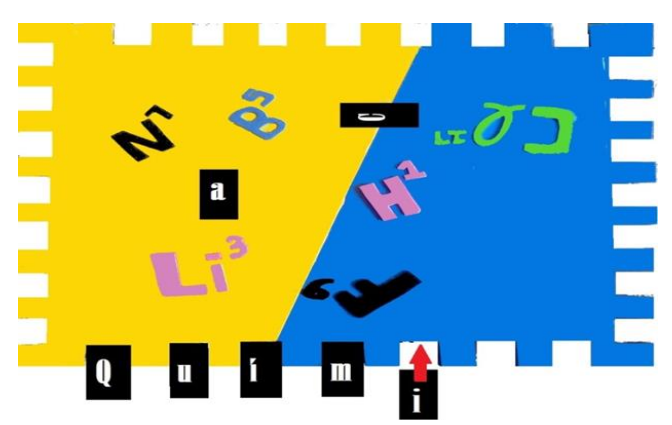

Figura 01- Imagem do Tabuleiro

O Quiz Química pode ser jogado de forma individual ou em grupos, os alunos irão respondendo às perguntas e de forma sistemática, colocando cada peça em seu devido lugar até formar a palavra Química, cada erro do jogador é retirado uma peça dele, cada indivíduo ou grupo receberão três cartas que lhes darão direito de pedir ajuda ao professor ou repassar a pergunta para outro, grupo vale ressaltar que as perguntas foram voltadas para o estudo de Tabela Periódica. Vence o jogo quem completar o nome Química. RESULTADOS E DISCUSSÕES

Durante a aplicação os alunos se mostraram bastante motivados e interessados, apresentando, assim, maior facilidade em responder as perguntas realizadas sobre Tabela Periódica. Logo após a finalização do jogo, realizou-se um questionário sobre essa metodologia com os alunos, onde a maioria aprovou o jogo, e confirmou que aprende-se melhor através de lúdicos didáticos. Todos os alunos concordaram também que seria interessante o professor dividir o conteúdo de forma tradicional e diferenciada.

CONCLUSÃO

Com base na participação e nas respostas dos alunos pode-se concluir que o Quiz Química é uma ferramenta facilitadora para o ensino de Química, fazendo com o que o aluno aprenda de forma divertida. Sendo que está ferramenta didática pode ser utilizada para o estudo de outros assuntos relacionados a Química.

REFERÊNCIAS

MELO,C. M.R. AS ATIVIDADES LÚDICAS SÃO FUNDAMENTAIS PARA SUBSIDIAR AO PROCESSO DE CONSTRUÇÃO DO CONHECIMENTO. Información Filosófica. V.2 nำ1 2005. 